\title{
Crab diversity as support for ecotourism activities in Pejarakan Mangrove Forest, Buleleng, Bali, Indonesia
}

\author{
I KETUT GINANTRA`, I KETUT MUKSIN, MARTIN JONI \\ Program of Biology, Faculty of Mathematics and Natural Sciences, Universitas Udayana. Jl. Raya Kampus UNUD, Bukit Jimbaran, South Kuta, Badung \\ 80361, Bali, Indonesia. Tel./fax.: +62-361-703137, ’email: ketut_ginantra@unud.ac.id
}

Manuscript received: 27 July 2021. Revision accepted: 7 September 2021.

\begin{abstract}
Ginantra IK, Muksin IK, Joni M. 2021. Crab diversity as support for ecotourism activities in Pejarakan Mangrove Forest, Buleleng, Bali, Indonesia. Biodiversitas 22: 4139-4145. This research aims to determine the diversity of crabs to support ecotourism activities in the coastal mangrove forest of Pejarakan Buleleng. Sampling of crabs was carried out using the square method, as many as 23 squares were spread over three mangrove zones, namely the front zone, the middle zone, and the rear zone. The number of individual crustacean species in each square plot was counted. Crab identification is based on morphological characters (shell color, claw shape, body-color, body size). Habitat use activities are observed directly. The diversity of crabs was calculated using the Shannon-Wiener diversity index. The results showed that in the coastal mangrove area of Pejarakan Buleleng, there were 11 species of crabs (9 species of crabs and 2 species of hermit crabs). Species diversity is in the medium category (index 2.25) and evenness index is high ( $\mathrm{E}=0.93$, mangrove conditions are stable). The seaward mangrove zone shows a higher diversity of crab species than the middle zone and the rear zone. The species of crabs that are quite abundant in the three zonings are Uca vocans, Chiromanthes sp., and Coenobita sp. Characteristics of crabs, activities, habitat use in mangrove zoning are attractions for ecotourism activities.
\end{abstract}

Keywords: Crabs, ecotourism attractions, mangroves, species diversity

\section{INTRODUCTION}

The mangrove forest in the coastal area of Pejarakan Village which covers an area of 160 hectares is managed by the Putri Menjangan Conservation Forum (NCF Putri Menjangan). Area management includes mangrove conservation efforts and the development of educational tourism/ecotourism (Riyastini 2015; NCF Putri Menjangan 2016). Ecotourism activities are principally the use of mangrove areas while maintaining the biological/ecological functions of mangrove forests and having economic value for local communities (Duangjai et al. 2014; Sudarto 1999).

Data on the diversity of mangroves, birds, and mollusks species in the Putri Menjangan NCF mangrove ecosystem are available. There were 13 species of true mangroves and 14 species of associated mangroves, the dominant species were Sonneratia alba, Lumnitzera racemose, Rhizophora apiculate, Rhizophora mucronata, Ceriops decandra, and Avicennia marina (Ginantra et al. 2018). There were 39 species of birds, including 24 families, the dominant species being from the waterbird groups of the Ardeidae and Alcedinidae families (Ginantra et al. 2020). Mollusks are dominated by the gastropod class including Terebralia palustris, Planaxis sulcatus, and Telescopium telescopium (Ginantra et al. 2020). However, there are no data available on the diversity of Crustacea in this area. Furthermore, the diversity of crabs also characterizes the quality of mangroves and is an attraction for ecotourism activities.

Malacostraca is an important macro-fauna group in the mangrove ecosystem, consisting of crabs, shrimp, and hermit crabs. Crabs are omnivorous animals that live in association with mangroves, eating carrion, algae, microbes, and detritus (Ravichandran et al. 2011). Crustaceans in mangrove areas have an important role in maintaining the balance of the food chain as prey and predators of other biota and as a source of community protein. Crab is a benthic animal that eats suspended material (filter feeders) and is generally very dominant on sandy and muddy substrates. The species found are shrimp and crab species that usually live in tidal areas and are included in the category of eating mangrove litter and fresh mangrove leaves (Widyastuti 2016).

Identification of crab species diversity is important because the diversity of crabs that interacts with mangrove ecosystems and patterns of diversity in habitat zoning is an attraction for ecotourism activities. This data could also be a reference for mangrove area managers (NCF Putri Menjangan) in developing ecotourism and mangrove forest conservation efforts.

\section{MATERIALS AND METHODS}

\section{Study area and period}

The research was conducted in April-June 2019, in the mangrove ecosystem area of the Putri Menjangan Conservation Forum, Peisisir, Pejarakan Village, Buleleng District, Bali, Indonesia (Figure 1). Field observations were carried out in the morning at $08.00-11.00$ and at 16.0018.00 Central Indonesian time in the afternoon. ZL1 to ZL8 is the square of the front zone sample (zone near the sea), ZT1 to ZT8 is the middle zone and ZD1-ZD7 is the 
back/land zone sample.

\section{Sampling technique}

A sampling of crabs was carried out in 23 square plots. Each square measured $1 \mathrm{~m} \times 1 \mathrm{~m}$. Placement of squares was based on mangrove zoning (from near the sea to the mainland) (Figure 1). Sampling was carried out at low tide, at each predetermined square, the substrate was excavated to a depth of $20 \mathrm{~cm}$. In each square plot, the number of individual crabs species was counted. Crabs were put in bottles and preserved with alcohol $(70 \%)$, then identified in the laboratory.

\section{Identifying the species of Crustaceae}

All specimens were photographed and identified. Identification of crustaceans based on morphological characters (shell color, claw shape, body-color, body size), identification refers to Motoh and Kuronuma 2015; Harshith et al. 2016; Lapolo et al. 2018). The identification of crustaceans was carried out in the Animal Taxonomy Laboratory of the Biology Study Program, Faculty of Mathematics and Natural Sciences, Udayana University, Bali, Indonesia.

\section{Determination of crustacean activity}

The activity of crabs in the habitat was observed directly, namely recording all activities found in each location of the mangrove ecosystem. Activity observations were carried out in 3 zones (front, middle, and rear). The data recorded is the activity of each species of crustacean (eating, walking, sticking to rocks/mangrove vegetation, entering the hole, getting out of the hole, entering the mud, entering the water). Observation of each crab activity was carried out for 10 minutes.

\section{Data analysis}

Crustacean diversity was calculated by the ShanonWiener diversity index $(\mathrm{H})=-\sum[\mathrm{ni} / \mathrm{N} \times \mathrm{Ln} n \mathrm{ni} / \mathrm{N})$, where $\mathrm{ni}=$ the significance value of the ith species and $\mathrm{N}=$ the total significance value of all species. The importance value is determined from 2 parameters, namely: relative density and relative frequency. The criteria for the diversity index are; $H^{\prime}<1.5$ then the species diversity is low, $1.5<\mathrm{H}^{\prime}<3.5$ means that the species diversity is moderate, and $H^{\prime}>3.5$ then the species diversity is high (Krebs 1989). The evenness index (E) is calculated by the formula, $\mathrm{E}=$ $\mathrm{H} / \mathrm{lnS}$, where $\mathrm{H}$ is the diversity index and $\mathrm{S}$ is the number of species. The uniformity index criteria are; if $0<\mathrm{E} \leq 0.5$ then the mangrove condition is depressed and uniformity is low, if $0.5<\mathrm{E} \leq 0.75$ then the condition is less stable and the uniformity is moderate, and if $0.75<\mathrm{E} \leq 1.0$ stable condition and high uniformity (Stiling 1996; Krebs 1989; Natania et al. 2017).

Habitat of crustaceans is presented descriptively in the form of tables. Analysis of the existence of crustaceans as an attraction for ecotourism refers to the results of the feasibility analysis of mangrove ecosystems as ecotourism objects according to Sari (2015) and Rahmila and Halim (2018).

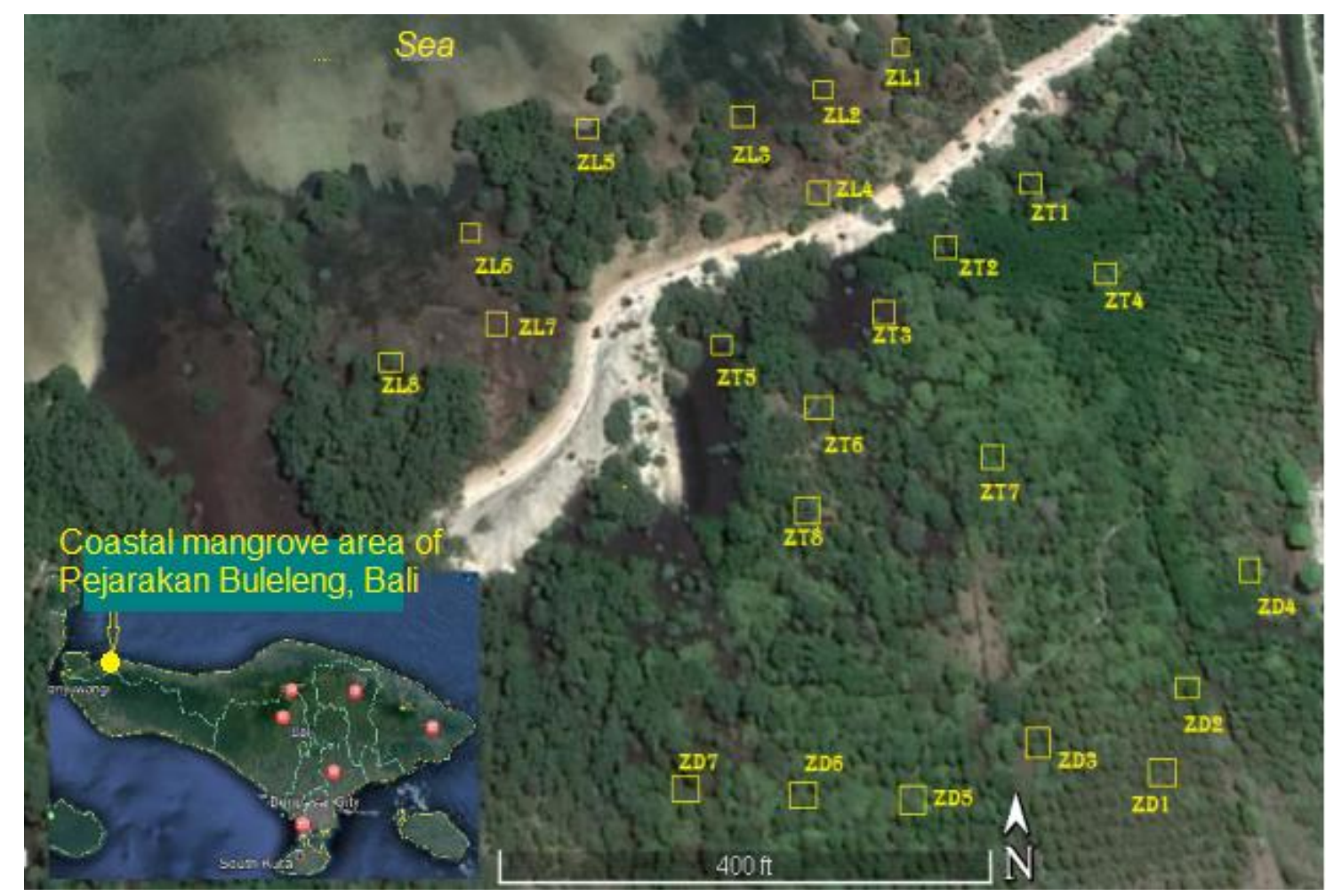

Figure 1. Research location map mangrove ecosystem area in the Putri Menjangan Conservation Forum, Peisisir, Pejarakan Village, Buleleng District, Bali, Indonesia 


\section{RESULTS AND DISCUSSION}

\section{Crustacean diversity}

The study results found 11 species of crustaceans, consisting of 8 species of crabs and 2 species of hermit crabs. The dominant species in the three mangrove zones is Coenobita $\mathrm{sp}$. With a density of $59 \mathrm{ind} / \mathrm{m}^{2}$, Uca vocans has a density of 41 ind. $/ \mathrm{m}^{2}$ and Chiromanthes sp. with a density of 38 ind. $/ \mathrm{m}^{2}$, but in general, the species of crustaceans found were fairly evenly distributed in density with one another. There are several species found only in one zone, namely Scylla sp., Sesarma sp. Uca anulipes and Uca tetragonon (sea zone), Uca sp. (middle zone) (Table 1, Figure 2).

The diversity of crabs in the Putri Menjangan mangrove area is moderate with a diversity index of 2.25 and a species evenness index of 0.93 (Figure 3), which means that the species composition is fairly even. Based on the diversity index, it can be said that the condition of mangroves in this area is still quite good.

The highest diversity of crustacean species is in the front (sea) zone, followed by the middle zone (Figure 3 ). In the front and middle zones, the density of plant mangrove species is quite high so that it produces a lot of mangrove litter which is the most important intake for mangrove crabs. This is in accordance with Ravichandran et al. (2011) stated that one of the factors that influence the diversity of mangrove crabs is the availability of natural food originating from mangroves and the presence of mangrove leaves. The results study by Ginantra et al. (2020) on mangrove vegetation and substrates show that the sea mangrove zone of Pejarakan coastal mangrove, has more complex vegetation, and consists of Sonneratia alba, Rhizophora apiculata, Rhizophora mucronata, Avicennia marina, Lumnitzera apiculata, Ceriops decandra, Ceriops tagal, and Aegiceras floridum. There are more diverse types of mangrove roots, namely pneumatophore, knee root, and stilt root. A more diverse type of substrate, namely Sandy, gravel, rock, shallow mud depth up to 10 $\mathrm{cm}$. Water level is high enough when the tide is high or low. Seagrass meadows are also found in some parts of the marine zone of the mangrove ecosystem of Pejarakan Buleleng.
Crabs diversity is higher in the sea zone and lowest in the landward zone Crab Uca spp. found more in the sea zone. The complexity of mangrove vegetation, substrate type, and the presence of seagrass in the sea zone support the high diversity of crustaceans. Pratiwi et al. (2018), also found that crustacean diversity (especially $U c a$ spp.) at a mangrove in Kema North Sulawesi was higher in the marine and middle zones than in the landward zone.

Crabs diversity plays a vital role in the mangrove ecosystem. They decompose mangrove litter and increase the availability of nutrients for other flora and fauna. Crabs act as a bioturburator that includes nutrient cycling from mudflats and mangroves. Mangroves provide shelter for crabs from threats from other benthic fauna. The existence of crabs directly depends on mangrove resources for survival and adaptation to various conditions of sediments. The distribution and diversity of crabs are related to several parameters including substrate $\mathrm{pH}$, nitrogen, potassium, phosphorus, and soil organic carbon (Saher and Qureshi 2011; Murugan and Anandhi 2016; Prasanna et al. 2017; Kamaruddin et al. 2019; Karniati et al. 2021).

The low diversity of crustacean species in the terrestrial zone is also caused by environmental pressures due to human activities, waste from salt pools in the form of mud, and solid waste that enters the mangroves. During our research, we found that a lot of waste from salt ponds enters the mangrove area of the land/back zone. Waste (including plastic, broken bottles, broken glass) can interfere with crustacean breeding grounds. Waste can also cover the surface of the substrate/mangrove roots containing food ingredients to prevent crustaceans from eating.

High and low tides in mangrove areas contribute to the existence of crabs, which can take food during low tide. Mangrove crabs are quite adaptive to environmental changes in their habitat, they will move if their habitat is disturbed (Lapolo et al. 2018). The results showed that crab species including Uca sp., Chiromanthes sp., and Sesarma roberti were often found in holes with relatively stable temperatures to adapt to extreme environments. Lapolo et al. (2018) stated that Uca spp. are commonly found in open areas and important in the mangrove ecosystem. These species have a habit of eating litter and leaves from mangrove seedlings or newly growing mangrove seedlings.

Table 1. Diversity and abundance of crabs crustaceans (ind. $/ \mathrm{m}^{2}$ ) in three coastal mangrove zones

\begin{tabular}{|c|c|c|c|c|c|}
\hline \multirow{2}{*}{ Class/Family } & \multirow{2}{*}{ Species } & \multicolumn{3}{|c|}{ Mangrove zone } & \multirow{2}{*}{ Total } \\
\hline & & $\mathbf{Z L}$ & ZT & ZD & \\
\hline Malacostraca/ Sesarmidae & Chiromanthes sp. & 11 & 11 & 16 & 38 \\
\hline Malacostraca / Sesarmidae & Sesarma roberti & - & 11 & 17 & 28 \\
\hline Malacostraca /Sesarmidae & Sesarma sp. & 11 & - & - & 11 \\
\hline Malacostraca /Ellobiidae & Scylla sp. & 12 & - & - & 12 \\
\hline Malacostraca /Corbiculidae & Uca anulipes & 10 & - & - & 10 \\
\hline Malacostraca /Corbiculidae & Uca sp. & - & 16 & - & 16 \\
\hline Malacostraca /Corbiculidae & Uca tetragonon & 11 & - & - & 11 \\
\hline Malacostraca /Corbiculidae & Uca vocans & 13 & 15 & 13 & 41 \\
\hline Malacostraca/Xanthidae & Etisus sp. & 4 & 2 & - & 6 \\
\hline Malacostraca /Coenobitidae & Coenobita sp. & 32 & 18 & 9 & 59 \\
\hline \multirow{3}{*}{ Malacostraca /Diogenidae } & Diogenes sp. & 13 & - & 9 & 22 \\
\hline & Total individual & 117 & 80 & 64 & 262 \\
\hline & Total species & 9 & 7 & 5 & - \\
\hline
\end{tabular}

Note: ZL: sea zone; ZT: middle zone; ZD: rear zone 


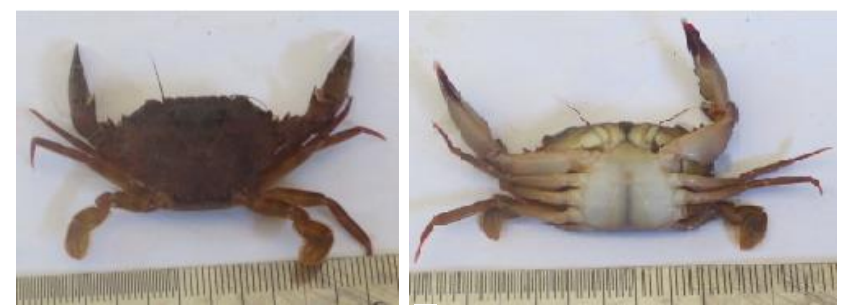

A

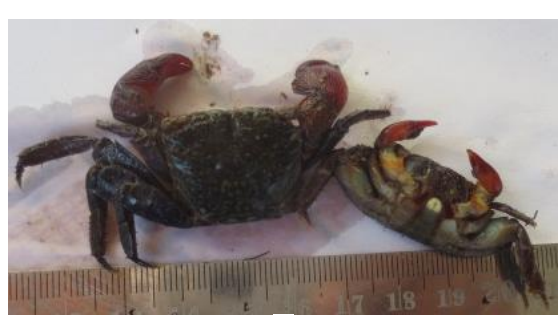

B

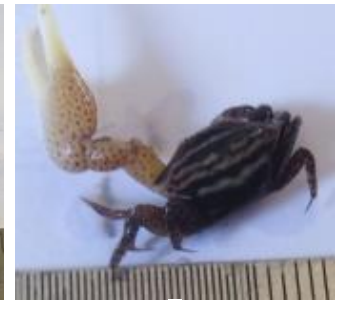

c

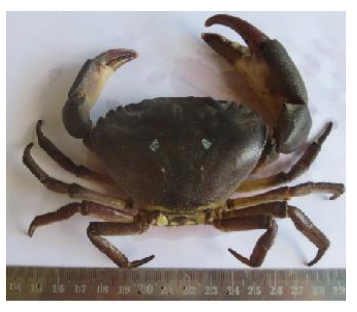

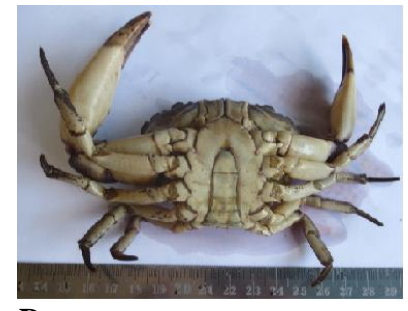

D
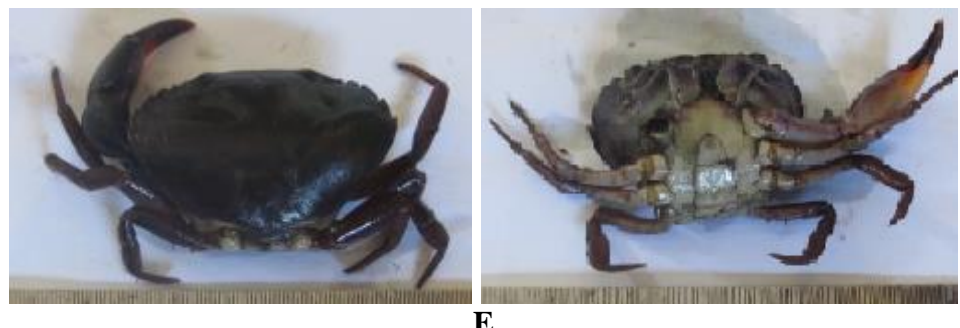

$\mathbf{E}$

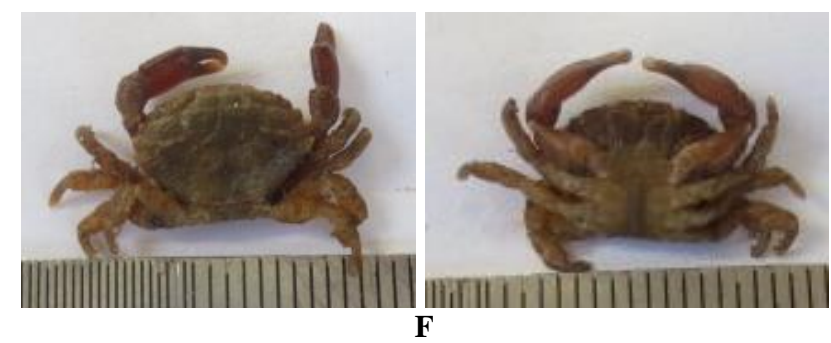

$\mathbf{F}$

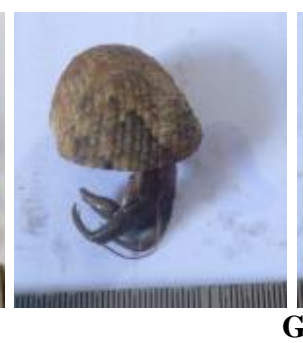

G
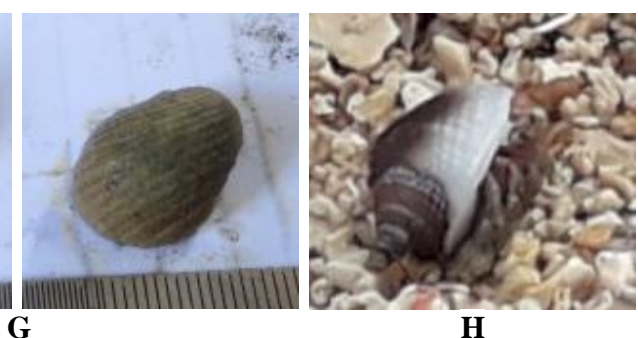
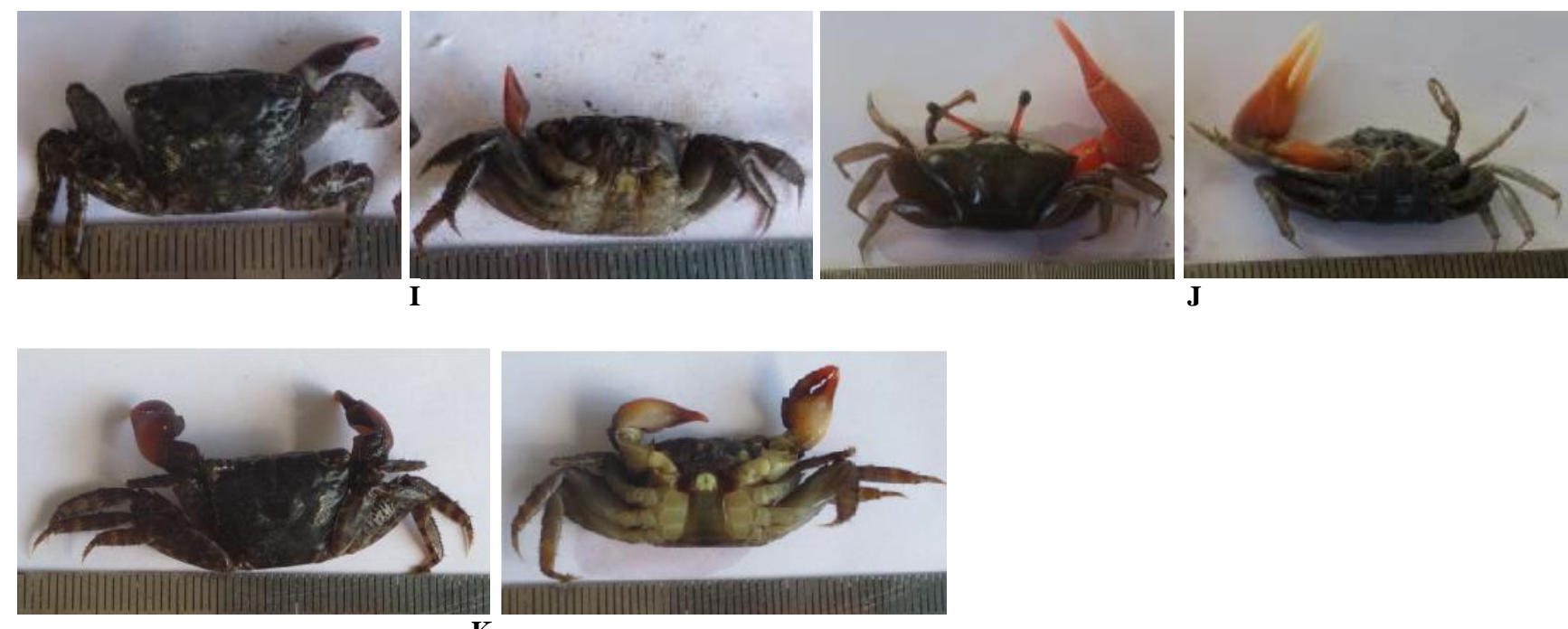

K

Figure 2. Species of Crustaceans in the coastal mangrove forest of Pejarakan Buleleng. A. Scylla sp.; B. Chiromanthes sp.; C. Uca anulipes; D. Uca tetragonon; E. Uca sp.; F. Etisus sp.; G. Caenobita sp.; H. Diogenes sp.; I. Sesarma roberti; J. Uca vocans; K. Sesarma sp.

Some species of crabs are quite low in number and are only distributed in the marine zone, namely Scylla sp. Uca anulipes, Sesarma sp. and Etisus sp. Several factors could cause the low population of this crab, including the substrate, mangrove plants, seagrass, and human disturbance. Scylla sp. is the edible type, so it is vulnerable to hunting. Lapolo et al. (2018) also reported that the crab Scylla spp. are hunted and caught using traditional traps in the mangrove habitat of Tanjung Panjang, Gorontalo. We have found that Scylla sp. is quite specific to the sandy substrate in mangroves. Kamaruddin et al. (2019) also found that the crab Scylla sp. are more commonly found on sandy substrates in mangrove habitats at Sungai Pinang village, Lingga. Anggraeni et al. (2015) also stated that Uca sp. lives in a mangrove ecosystem with a sand bottom substrate in the coastal mangrove ecosystem of Tikus island. Anggorowati (2014) stated that the genus Etisus is common in seagrass beds. 


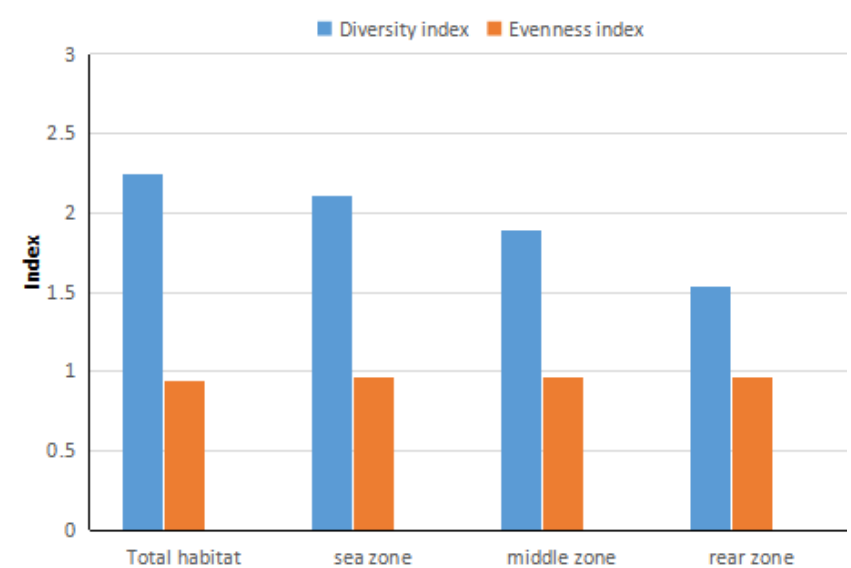

Figure 3. Diversity of crabs species in three mangrove zones

\section{Crab diversity in the mangrove ecosystem as an ecotourism attraction}

Information on the species found, their status of existence whether protected or not, rare or common, is important information in ecotourism activities. Activities and habitat use by crustaceans that were observed to stick to mangrove roots, cling to rocks, walk on sand/gravel, walk, enter holes, enter in the mud looking for food and walk on mudflats are interesting attractions for observing mangrove crustaceans. The observed activity data are presented in Figure 4 and Table 2.

Observation of crustaceans begins with field activities, namely by directly observing the fauna in the mangrove area. Ecotourism guides for observing mangrove fauna should have excellent competence (knowledge, expertise, and behavior) to interpret and explain the overall fauna of the mangrove forest habitat well. To assist ecotourism guides in observing fauna to interpret them well, it is necessary to prepare a handbook for crabs identification.

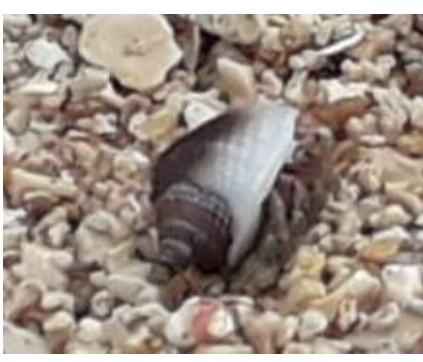

A

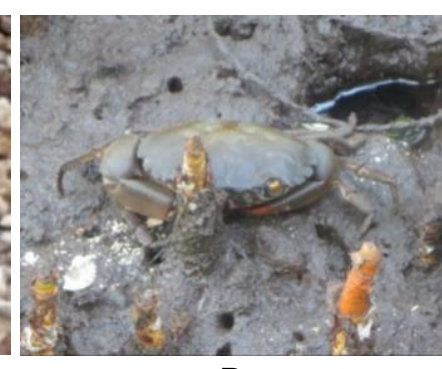

B

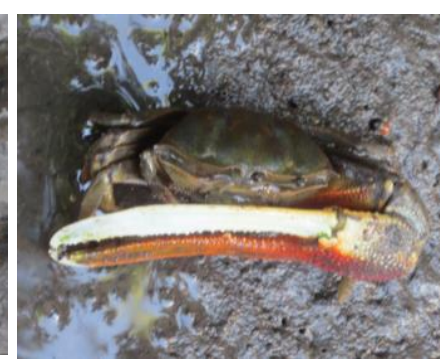

C

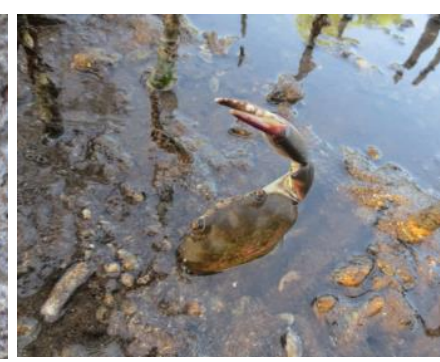

D

Figure 4. Crabs activity in Pejarakan coastal mangrove (A. hermit crabs are walking on gravel; B. crabs are eating around mangrove roots; C. crab walks in the mud; D. crab in the mud)

Table 2. Observable crabs activity in Pejarakan Coastal mangrove

\begin{tabular}{|c|c|c|c|}
\hline \multirow{2}{*}{ Species } & \multicolumn{3}{|c|}{ Mangrove zone } \\
\hline & $\mathbf{Z L}$ & ZT & ZD \\
\hline Chiromanthes sp. & Eat around the mangrove roots & $\begin{array}{l}\text { Walk in the mud, enter the } \\
\text { hole }\end{array}$ & Eat around the mangrove roots \\
\hline Sesarma roberti & Eat in the litter in the mud & $\begin{array}{l}\text { Walk in the mud, enter the } \\
\text { hole }\end{array}$ & $\begin{array}{l}\text { Walk in the mud, enter the } \\
\text { hole }\end{array}$ \\
\hline Sesarma sp. & Get out of the hole & - & - \\
\hline Scylla sp. & Walking on the rock & - & - \\
\hline Uca anulipes & $\begin{array}{l}\text { Eating in the litter on the mudflat, out of the } \\
\text { hole, into the water, making a sound }\end{array}$ & - & - \\
\hline Uca dussumieri & - & Enter the hole & - \\
\hline Uca tetragonon & Get in the hole, get into the mud & - & - \\
\hline Uca vocans & $\begin{array}{l}\text { Eating around the mangrove roots, making } \\
\text { sounds }\end{array}$ & $\begin{array}{l}\text { Eat around the mangrove } \\
\text { roots }\end{array}$ & $\begin{array}{l}\text { Eating around the mangrove } \\
\text { roots, making a sound }\end{array}$ \\
\hline Etisus sp. & Enter the hole & Enter the hole & - \\
\hline Coenobita sp. & $\begin{array}{l}\text { Clinging to the mangrove roots, walking on } \\
\text { gravel }\end{array}$ & Sticking to the rock & Walking on mangrove roots \\
\hline Diogenes sp. & Walking on gravel & - & Walking in the mud \\
\hline
\end{tabular}

Note: ZL: sea zone; ZT: middle zone; ZD: rear zone; - : species not found in the zone 
In the handbook, it is necessary to display photos of the species of crabs, their morphological, ecological, and status characteristics. This information is important for both novice and experienced observers. The information in this handbook is also important to increase the insight and knowledge of ecotourists about the existence of crabs. Here are some species of mollusks and crustacean groups in the mangrove ecosystem that show interesting attractions. Some species are clinging to the coral, on the rocks, there are species of crabs walking in the mud.

Ecotourism attractions in the coastal mangrove area of Pejarakan and recreation are also important as educational tours. So the tourists do not just go around enjoying the expanse of mangroves. The introduction of species diversity, uniqueness of fauna, especially crabs, as a habitat for various aquatic and terrestrial fauna, is an important part of educational tourism.

The utilization of mangroves for ecotourism activities plays an important role in preserving fauna and mangrove ecosystems and provides economic value for local communities. Duangjai et al. (2014) showed that ecotourism activities in mangrove areas can provide a sustainable source of income for local communities and increase awareness of environmental services and the benefits of mangrove ecosystems to the Mangrove Forest Community in Satun Province, Thailand. Rahmila and Halim (2018); Sari et al. (2015) state that the feasibility of mangrove areas for ecotourism, in addition to the diversity of mangroves, is a characteristic of mangrove habitats (tidal, mud). Accessibility and diversity of fauna (mollusks, crustaceans, insects, reptiles, birds, fish and mammals). The diversity and activity of crustaceans are one of the supporting factors for the preservation of mangrove forests for ecotourism activities.

The sustainability of mangrove areas and the ecotourism business is highly dependent on a diversity of living things (including diversity of crustaceans, mollusks, birds, and mangrove plants), so it is important to reduce the loss of biodiversity. Stakeholders and policymakers need to integrate consideration of biodiversity and area management for tourism purposes. The contribution of local communities near mangroves in developing mangroves for tourism is very important (Hakim et al. 2017; Malik et al. 2019). In the coastal mangroves of Pejarakan, a local community forum is interested in managing mangroves for tourism is the Nature Conservation Forum (NCF) Putri Menjangan. This forum combines the concepts of mangrove biodiversity conservation and tourism.

In conclusion, the diversity of crabs species in the Putri Menjangan mangrove area is in the medium category (diversity index 2.25). Found 9 species of crabs and 2 species of hermit crabs. The marine mangrove zone shows a higher diversity of crabs species than the middle and land zones. Crab characteristics, activities, habitat use activities in mangrove zoning is an attractive attraction for ecotourism activities.

In recommendation, it is necessary to replant mangrove areas that are still open to increase the diversity of mangrove species, increasing the diversity of interacting crabs. In the development of mangroves for ecotourism attractions, the trail should be built to a minimum of changing the landscape of the mangrove area because it will affect the availability of habitat for crabs.

\section{ACKNOWLEDGEMENTS}

We would like to thank the Institute for Research and Community Service, Faculty of Mathematics and Natural Sciences, Udayana University, Indonesia which has funded this research. Thanks to Gatot (NCF, Putri Menjangan) who has facilitated the research in the field. Thanks to Yeyen Suharta, Oka Vidyawedanta for helping in the sample collection in the field.

\section{REFERENCES}

Anggraeni P, Elfidasari D, Pratiwi R. 2015. Sebaran kepiting (Brachyura) di Pulau Tikus, Gugusan Pulau Pari, Kepulauan Seribu. Prosiding Seminar Nasional Masyarakat Biodiversitas Indonesia. Depok, 20 Desember 2014. [Indonesia]

Anggorowati DA. 2014. Community structure of crustacea fauna at the intertidal zone of west Lombok. Zoo Indonesia 23 (2): 92-100. [Indonesia]

Duangjai W, Tuntates U, Kroeksakul P. 2014. The Comparative Evaluation of Community-based Ecotourism Management at Mangrove Forest Communities in Satun Province, Thailand. Intl J Emerg Technol Adv Eng 4 (6): 42-48.

Hakim L, Siswanto D, Nakagoshi N. 2017. Mangrove conservation in East Java: The ecotourism development perspectives. J Trop Life Sci 7 (3): 277-285. DOI: 10.11594/jtls.07.03.14

Harshith UP, Apoorva MD, Precilla, D'Silva, Anita DD. 2016. Crabs diversity in mangrove and coastal ecosystem. Proceeding Lake 2016. India, 28-30 December 2016.

Ginantra IK, Muksin IK, Suaskara IBM, Joni M. 2020. Diversity and distribution of mollusks at three zonas of mangrove in Pejarakan, Bali, Indonesia. Biodiversitas 21 (10): 4636-4643. DOI: 10.13057/biodiv/d211023

Ginantra IK, Muksin IK, Joni M. 2020. Diversity of birds for ecotourism attractions in the mangrove ecosystem of Nature Conservation Forum Putri Menjangan, Buleleng Bali. J Environ Manag Tour 11 (1): 105113. DOI: 10.14505//jemt.v11.1(41).07

Ginantra IK, Suaskara IBM, Joni M. 2018. Diversity of mangrove plant for support ecotourism activities in Nature Conservation Forum Putri Menjangan, Pejarakan Buleleng-Bali. J Environ Manag Tour 5 (29): 987-994. DOI: 10.14505//jemt.v9.5(29).10

Kamaruddin E, Siregar YI, Saam Z, Sukendi. 2019. Diversity and abundance of Scylla spp. in mangrove habitat at Sungai Pinang village, Lingga. Biodivers Intl J 3 (6): 235-239. DOI: 10.15406/bij.2019.03.00150

Karniati R, Sulistiyono N, Amelia R, Slamet B, Bimantara, Basyun M. 2021. Mangrove ecosystem in North Sumatran (Indonesia) forests serves as a suitable habitat for mud crabs (Scylla serrata and $S$. olivacea). Biodiversitas 22 (3): 1489-1496. DOI: 10.13057/biodiv/d220353

Krebs JC. 1989. Ecological Methodology 3nd Edition. Addison Welsey, United States

Lapolo NR, Utina D, Wahyuni, Baderan K. 2018. Diversity and density of crabs in degraded mangrove area at Tanjung Panjang Nature Reserve in Gorontalo, Indonesia. Biodiversitas 19 (3): 1154-1159. DOI: 10.13057/biodiv/d190351

Malik A, Rahim A, Sideng U, Rasyid A, Jumaddin J. 2019. Biodiversity assessment of mangrove vegetation for the sustainability of ecotourism in West Sulawesi, Indonesia. AACL Bioflux 12 (4): 14581466.

Motoh H, Kuronuma K. 2015. Field Guide for the Edible Crustacea of the Philippines Southeast Asian Fisheries Development Center (Seafdec) Aquaculture Department, Iloilo, Philippines. SEAFDEC Aquaculture Department, Philippines. 
Murugan S, Anandhi DU. 2016. An overview of crustacean diversity in mangrove ecosystem. In: Chakravarthy, Kumar A, Sridhara Shakunthala (eds). Arthropod Diversity and Conservation in the Tropics and Sub-tropics. Springer, Germany.

NCF Putri Menjangan. 2016. Profil of NCF Putri Menjangan Bali. [Report]. Pejarakan Village, Indonesia.

Natania TNE, Herliany, Kusuma AB. 2017. Struktur komunitas kepiting biola (Uca spp.) di ekosistem mangrove Desa Kahyapu Pulau Enggano. Jurnal Enggano 2 (1): 11-24. [Indonesia]

Prasanna J, Seshapria V, Anand M, Kumaraguru AK, Rangesh K. 2017. Biodiversity assessment of crabs, gastropod and bivalves in Chinnapalam Creek, of the Southeast Coast of India. Indian J Geo Mar Sci 46 (09): 1751-1757.

Pratiwi R, Widyastuti E, Guangcheng C, Shunyang C.2018. Diversity and abundance of mangrove fiddle crabs, genus Uca (Decapoda Ocypodidae) at a mangrove in Kema, North Sulawesi, Indonesia. Acta Oceanologica Sinica 7 (12): 92-96. DOI: 10.1007/s13131-0181336-8

Rahmila YI. and Halim MAR. 2018. Mangrove forest development determined for ecotourism in Mangunharjo Village Semarang. E3S Web Conf 73: 04010. DOI: 10.1051/e3sconf/20187304010
Ravichandran S, Fredrick WS, Khan SA, Balasubramanian T. 2011. Diversity of mangrove crabs in South and southeast Asia. J Oceanogr Mar Environ Syst 1 (1): 01-07.

Riyastini IAP. 2015. Mangrove Economic Valuation of Pejarakan Village, Gerokgak District, Buleleng Regency. Bali Provincial Marine and Fisheries Service, Indonesia.

Saher NU, Qureshi NA. 2011. Diversity and Distribution of Mangrove Crabs in Three Intertidal Ares of Balochistan, Pakistan. Pak J Mar Sci 20 (1\&2): 27-36.

Sari IP, Yoza D, Sribudian E. 2015. Analisis kelayakan ekosistem mangrove sebagai objek ekowisata di Desa Teluk Pambang Kecamatan Bantan Kabupaten Bengkalis. Jurnal Online Mahasiswa 2 (1): $1-10$.

Stiling P. 1996. Ecology, Theories and Applications. Prentice Hall Internationan Inc, New Jersey.

Sudarto, G. 1999. Ekowisata. Efforts to Conserve Nature, Sustainable Economic Development and Community Empowerment. The Kalpataru Bahari Foundation and the Indonesian Biodiversity Foundation, Indonesia.

Widyastuti. E. 2016. Keanekaragaman kepiting pada ekosistem mangrove di Perairan Lingga Utara dan sekitarnya, Kepulauan Riau. Zoo Indonesia 25 (1): 22-32. [Indonesia] 